\title{
Septic shock due to refractory severe clostridioides difficile colitis rapidly resolving after faecal microbiota transplantation
}

\author{
Nicolas Benech, ${ }^{1,2}$ Gilles Leboucher, ${ }^{3}$ Céline Monard, ${ }_{1}^{4}$ Tristan Ferry (1) 1,2,5
}

\begin{abstract}
${ }^{1}$ Service des Maladies Infectieuses et Tropicales, Hôpital de la Croix-Rousse, Hospices Civils de Lyon, Lyon, Rhône-Alpes, France ${ }^{2}$ Université Claude Bernard Lyon, Lyon, France ${ }^{3}$ Service de Pharmacie Hospitalière, Hôpital de la CroixRousse, Hospices Civils de Lyon, Lyon, France

${ }^{4}$ Service de Réanimation Chirurgicale, Pavillon P, Hôpital Edouard Herriot, Hospices Civils de Lyon, Lyon, France ${ }^{5} \mathrm{CIRI}$ - Centre International de Recherche en Infectiologie, Inserm U1111, Université Claude Bernard Lyon 1, CNRS, UMR5308, Ecole Normale Supérieure de Lyon, Univ Lyon, Lyon, France
\end{abstract}

\section{Correspondence to} Dr Tristan Ferry; tristan.ferry@univ-lyon1.fr

Accepted 27 July 2020

\section{DESCRIPTION}

An 80-year-old woman presented with septic shock and severe colitis at the intensive care unit. Her main personal medical history consisted of obesity, diabetes mellitus, high blood pressure and end-stage chronic kidney disease requiring dialysis. She was previously admitted to another hospital for traumatic wrist and patella fractures complicated with a Clostridioides difficile infection (CDI) that resolved after a 10-day course of oral metronidazole (500 mg/8 hours). She developed an eschar of the heel, complicated with local bone infection treated surgically with a prolonged clindamycin treatment. She was finally discharged with a high degree of dependence leading to hospitalisation at home. Three months later, under clindamycin therapy, the patient presented diarrhoea and emesis with altered consciousness, hypotension and hyperlactatemia $(2.7 \mathrm{mmol} / \mathrm{L} ; \mathrm{n}<2.2 \mathrm{mmol} / \mathrm{L})$ leading to her transfer to the intensive care unit. An abdominal CT scan showed important oedema of the colon mucosa mainly involving the sigmoid and rectum with no sign of perforation (figure 1A). PCR stool toxin test for $C$. difficile was positive and oral vancomycine (500 mg/6 hours) combined to intravenous metronidazole $(500 \mathrm{mg} / 8$ hours $)$ was started. Clinical evolution was not favourable with the persistent need of high dose of noradrenalin and important haematochezia leading to repetitive blood transfusions. Short colonoscopy showed a typical aspect of pseudomembranous colitis with deep ulcerations and spontaneous bleeding (figure 1B). Piperacillin/ tazobactam and amikacin antibiotics were also administered intravenously in the hypothesis of a bacterial translocation. Finally, all blood cultures

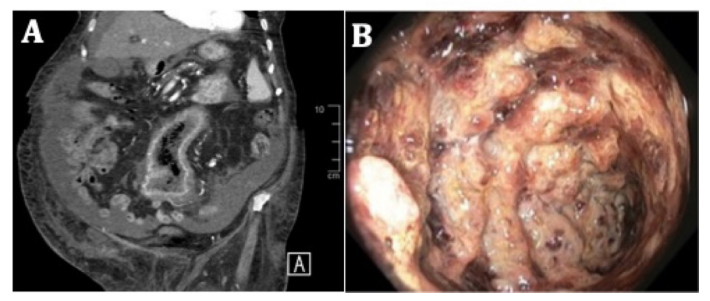

Limited 2020. No commercial re-use. See rights and permissions. Published by BMJ.

To cite: Benech N,
Leboucher G, Monard C,
et al. BMJ Case Rep
2020;13:e234329.
doi:10.1136/bcr-2020-
234329

Figure 1 Severe and complicated Clostridioides difficile infection resolving after faecal microbiota transplantation (FMT): (A) abdominal CT with contrast enhancement before FMT showing important colon wall thickening and free intra-abdominal fluid; (B) short colonoscopy findings showing severe and profuse ulceration with spontaneous bleeding. remained sterile and a colectomy was proposed. The patient and her family refused surgery and faecal microbiota transplantation (FMT) was decided. Piperacillin/tazobactam-amikacin and vancomycine-metronidazole were stopped respectively 5 days and 2 days before transplantation. Faecal transplant was prepared from fresh stools of a voluntary

\section{Patient's perspective}

Testimony from the daughter, the patient's primary caregiver:

My mother was severely ill when she was admitted to the intensive care unit. We were afraid that she would pass away. Doctors spoke about the possibility of a surgery with very high risk of complication and death. They proposed us to perform a faecal transplantation as an alternative to surgery but without certainty of efficacy. At first sight, I was not in favour of this treatment because I considered my mother too old for this kind of experimental procedure. However, after discussions with my family and my mother, we chose this treatment to avoid the high-risk surgery. My mother and I were not disgusted or afraid by the treatment itself; all the more it was administrated by nasogastric tube. We do not remember any specific immediate side effect or complication caused by the faecal transplantation itself but her health condition improved rapidly thereafter. Convalescence was very long anyway and it took 8 months before she could come back home. Since that time, she did not present any other gut infection. Today, we do not regret at all that she could benefit from this unusual treatment and avoid surgery.

\section{Learning points}

- Treatment of Clostridioides difficile colitis with metronidazole should be avoided and oral vancomycin treatment is now the reference for a first episode to prevent recurrence.
- Faecal microbiota transplantation (FMT) could be a therapeutic alternative to colectomy for severe and complicated $C$. difficile colitis.

- Symptoms improvement can occur rapidly after FMT in severe $C$. difficile colitis but multiple FMTs can be necessary. 
unrelated donor using $83 \mathrm{~g}$ of faeces diluted in $400 \mathrm{~mL}$ of $\mathrm{NaCl}$ $0.9 \%$. Administration of the transplant was performed through duodenal infusion after bowel preparation as recommended for non-complicated recurrent CDI given the fact that the risk of perforation was considered too high for colonoscopy and anal incontinence excluded the use of enema. Evolution was rapidly favourable with resolution of the diarrhoea within 6 hours, and vasopressors withdrawal at day 6 after FMT. At day 7 after FMT, PCR stool test for C. difficile was negative and a short colonoscopy showed only residual lesions. The patient was discharged 10 days after FMT with no additional specific treatment. After 2 years of follow-up, the patient did not exhibit any other recurrence of CDI.

FMT has demonstrated its efficacy to treat recurrent CDI and is now clearly recommended for this indication. ${ }^{12}$ Fewer data are available on safety and effectiveness of FMT in severe and complicated $C$. difficile colitis where risk of translocation is important. This case suggests that even in the case of deep ulceration with septic shock, FMT can be a safe alternative to colectomy for severe-complicated CDI and rapid clinical improvement can be expected. Other case series describing FMT in severe CDI showed good efficacy although, in some cases, multiple FMTs were required to obtain infection resolution. $^{34}$
Acknowledgements GLyTMi (Groupe Lyonnais de Transplantation de Microbiote) study group: Nicolas Benech, Tristan Ferry, Florence Ader, Thomas Perpoint, Florent Valour, Marielle Guillet, Claire Billoud, Ninon Soufflet, Gilles Leboucher.

Contributors NB wrote the draft of the manuscript. NB, GL, CM and TF participated in the patient care, the literature review and improvement of the manuscript.

Funding The authors have not declared a specific grant for this research from any funding agency in the public, commercial or not-for-profit sectors.

Competing interests None declared.

Patient consent for publication Next of kin consent obtained.

Provenance and peer review Not commissioned; externally peer reviewed.

\section{ORCID iD}

Tristan Ferry http://orcid.org/0000-0003-3082-7001

\section{REFERENCES}

1 van Nood E, Vrieze A, Nieuwdorp M, et al. Duodenal infusion of donor feces for recurrent Clostridium difficile. N Engl J Med 2013;368:407-15.

2 Debast SB, Bauer MP, Kuijper EJ. European Society of clinical microbiology and infectious diseases. European Society of clinical microbiology and infectious diseases: update of the treatment guidance document for Clostridium difficile infection. Clin Microbiol Infect Off Publ Eur Soc Clin Microbiol Infect Dis 2014;20:1-26.

3 Fischer M, Sipe B, Cheng Y-W, et al. Fecal microbiota transplant in severe and severecomplicated Clostridium difficile: a promising treatment approach. Gut Microbes 2017:8:1-14.

4 Cammarota G, laniro G, Kelly CR, et al. International consensus conference on stool banking for faecal microbiota transplantation in clinical practice. Gut 2019;68:2111-21.

Copyright 2020 BMJ Publishing Group. All rights reserved. For permission to reuse any of this content visit

https://www.bmj.com/company/products-services/rights-and-licensing/permissions/

BMJ Case Report Fellows may re-use this article for personal use and teaching without any further permission.

Become a Fellow of BMJ Case Reports today and you can:

- Submit as many cases as you like

- Enjoy fast sympathetic peer review and rapid publication of accepted articles

- Access all the published articles

Re-use any of the published material for personal use and teaching without further permission

Customer Service

If you have any further queries about your subscription, please contact our customer services team on +44 (0) 2071111105 or via email at support@bmj.com.

Visit casereports.bmj.com for more articles like this and to become a Fellow 